\title{
PRESENCE OF MICROORGANISMS AT VARIOUS STAGES OF POULTRY WASTES MANAGEMENT PART I. KERATINOLYTIC MICROORGANISMS
}

\author{
Ilona Wrońska ${ }^{1}, K^{2} y s t y n a$ Cybulska ${ }^{1}$ \\ 1 Department of Microbiology and Environmental Biotechnology, West Pomeranian University of Technology \\ in Szczecin, Słowackiego 17 Str., 71-434 Szczecin, Poland, e-mail: ilona.wronska@zut.edu.pl, krystyna. \\ cybulska@zut.edu.pl
}

Received: 2016.07.10 Accepted: 2016.09.26 Published: 2016.11.01

\begin{abstract}
Poultry waste management is a difficult and arduous process. This requires a number of steps of processing the organic substances included in the waste mass from poultry industry. These wastes, due to the high content of keratin, are hardly degradable. One of the possibilities of their decomposition is the use of highly-active microorganisms. The aim of the study was to determine the presence of keratinolytic microorganisms at the selected stages of poultry waste management. The research material consisted of slime originating from liquid waste reservoir, biological sludge, and proper compost. Analyses were performed on mineral substrates containing keratin as the only carbon source. Based on the study, the presence of keratinolytic microorganisms was found in all materials. The slime was the most numerously inhabited waste, while proper compost the least. Predominant group of microorganisms, regardless of the tested material type, was composed of bacteria.
\end{abstract}

Keywords: microorganisms, keratin, poultry waste, composting

\section{INTRODUCTION}

Consumption of poultry meat in Poland is growing every year, which resulted in a 2-fold increase in its production within 2000-2012. Its consumption was $26.5 \mathrm{~kg}$ per year per 1 inhabitant [GUS 2013]. Such increase generates increasing amounts of post-slaughter wastes. These are mainly fat and meat wastes with a high content of keratin protein. The waste, besides high content of organic substances, may contain microorganisms, including pathogenic ones [Marcinkowski, 2010; Cybulska et al., 2015].

Feathers are made of keratin, that is a fibrillar protein characterized by a resistance to physical and chemical as well as biological factors [Barone and Schmidt, 2006; Korniłłowicz-Kowalska and Bohacz, 2011]. These unique properties of keratin result from crosslinking by numerous chemical bonds including disulfide bridges and hydrogen bonds [Grazziotinetal.,2006; Mazotto etal.,2013].
A significant group of microorganisms has the ability to secrete the enzymes necessary for keratin degradation [Vasileva-Tonkova et al. 2009, Pillai and Archana, 2008]. Such ability was discovered at bacteria [Ichida et al., 2001, El-Refai et al., 2005; Cai et al., 2008], actinomycetes [Gousterova et al., 2005], and fungi [Rodrigues Marcondes et al., 2008; Godheja and Shekhar, 2014]. Keratinolytic microorganisms inhabit mostly feathers, but their occurrence was also found in sewage sludge [Ulfig et al., 1996] and soil [Brandelli et al., 2010]. These microorganisms may play a key role in poultry waste management. One of the directions of using the keratinolytic microorganisms in feathers utilization is to increase the feed value of the raw materials by improving the digestibility and enrichment in nutrients [Bo et al., 2009]. The effect of composting poultry waste on the inactivation of prions dangerous to the health of animals and humans, cannot be underestimated either [Xu et al., 2014]. 
The aim of the study was to determine the number of keratinolytic microorganisms at various stages of management and production of poultry waste compost.

\section{MATERIALS AND METHODS}

The assays were performed using selected poultry materials from the poultry processing composting plant in West Pomerania province. They included slime collected from the liquid wastes reservoir, sludge from biological sewage treatment plant, and proper compost (Figure 1). Materials for laboratory assays were collected on the following dates: I - March 5, 2015 yr., II - May 21, 2015 yr., III - June 25, 2015 yr., and IV - January 14, 2016 yr. During the sampling, following temperatures were recorded: date I $-3^{\circ} \mathrm{C}$, date II
- $13^{\circ} \mathrm{C}$, date III $-17^{\circ} \mathrm{C}$, date IV $-1^{\circ} \mathrm{C}$ [WIOŚ Szczecin]. The ambient temperature was specified for the measuring station at the Andrzejewski Street closest to the plant. Due to the location of part of the objects on the open space, i.e. composting facility, reservoir with liquid waste, and temporary storage of biological sludge, 4 research dates with different weather conditions, were selected.

In the waste catalog issued by the Minister of the Environment [Regulation... 2014], sludge from sewage treatment plant has code 020204 meaning "sludge from wastewater treatment plants". According to the current legislation, compost has code 190503 meaning "compost that do not meet requirements (unfit for use)". The slime is a semi-liquid waste arising within the wastewater treatment plant. For the determination of microorganisms number the serial dilution method was applied. Microorganisms were
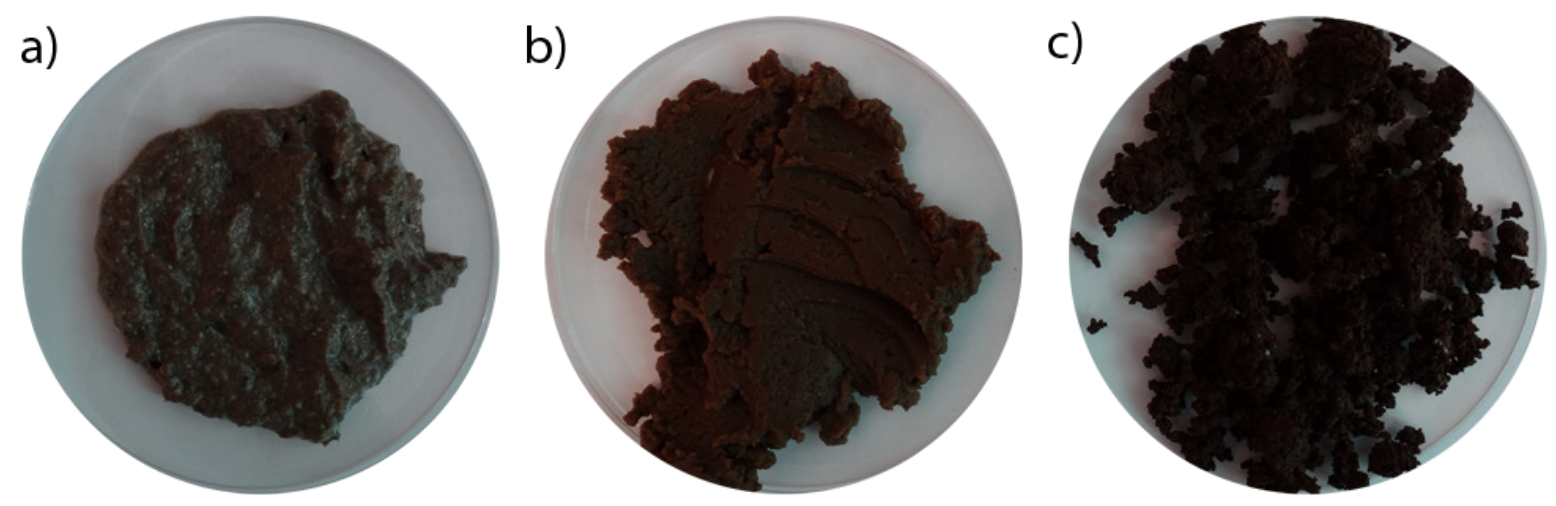

Figure 1. Tested materials: a) slime, b) biological sludge, c) proper compost

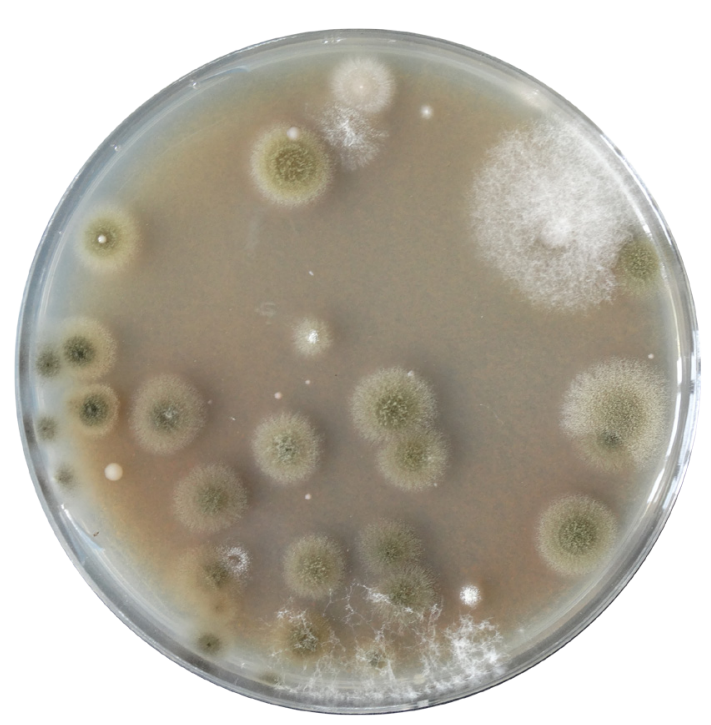

Figure 2. Growth of the fungi on Omeliański medium cultivated on two modified mineral media containing keratin as the only source of carbon. The first was Omeliański medium with the prevailing tendency of fungal growth (contents per 1 liter): 1 $\mathrm{g} \mathrm{KNO}_{3}, 1 \mathrm{~g} \mathrm{~K}_{2} \mathrm{HPO}_{4}, 0.5 \mathrm{~g} \mathrm{MgSO}_{4} \cdot 7 \mathrm{H}_{2} \mathrm{O}$, traces of $\mathrm{NaCl}, 10 \mathrm{~g}$ keratin, $20 \mathrm{~g}$ agar, the other was Mandela medium making possible to isolate mainly bacteria (Mandels and Weber, 1969). The number of keratinolytic microorganisms which are inhabiting tested wastes and products was specified. The cultures were incubated at $23-25^{\circ} \mathrm{C}$ for 7-14 days. The numbers of microorganisms were given as colony forming units (CFU) per $1 \mathrm{~g}$ dry mass. Microbiological assays were carried out in three replicates. Achieved results were subject to statistical analysis applying Statistica ver. 12 software. After analysis of result variance normality 
and homogeneity it was decided to use nonparametric ANOVA Kruskal-Wallis test. The average numbers of bacteria and fungi between two tested Mandel and Omeliański substrates were compared using a t-Student test.

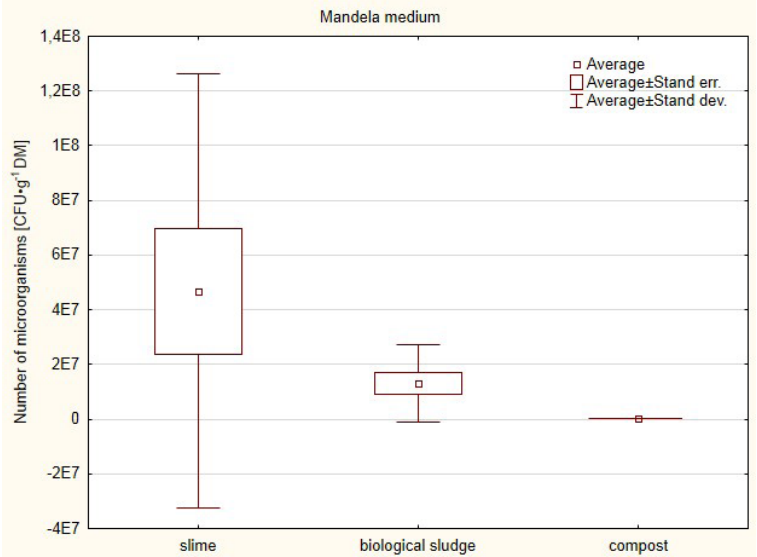

\section{RESULTS AND DISCUSSION}

Based on the analysis of the number of microorganisms capable of degrading keratin and colonizing poultry wastes, their varying contents

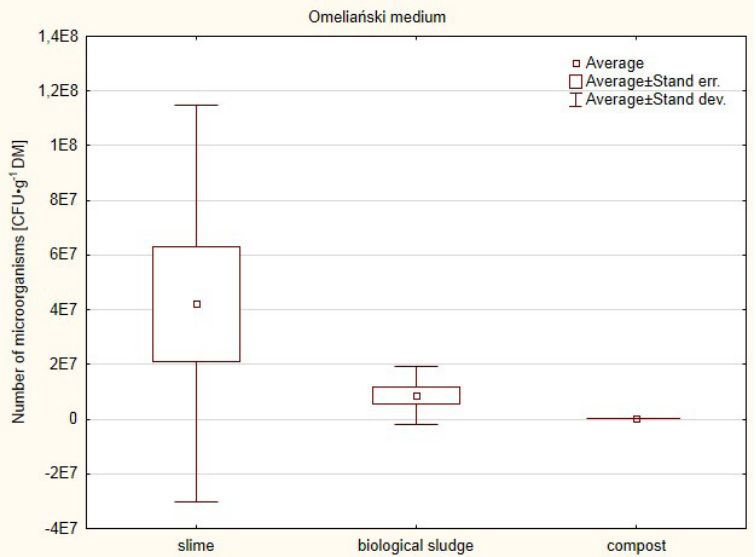

Figure 3-4. Average number of bacteria and fungi in tested materials on the example of two analyzed microbiological substrates
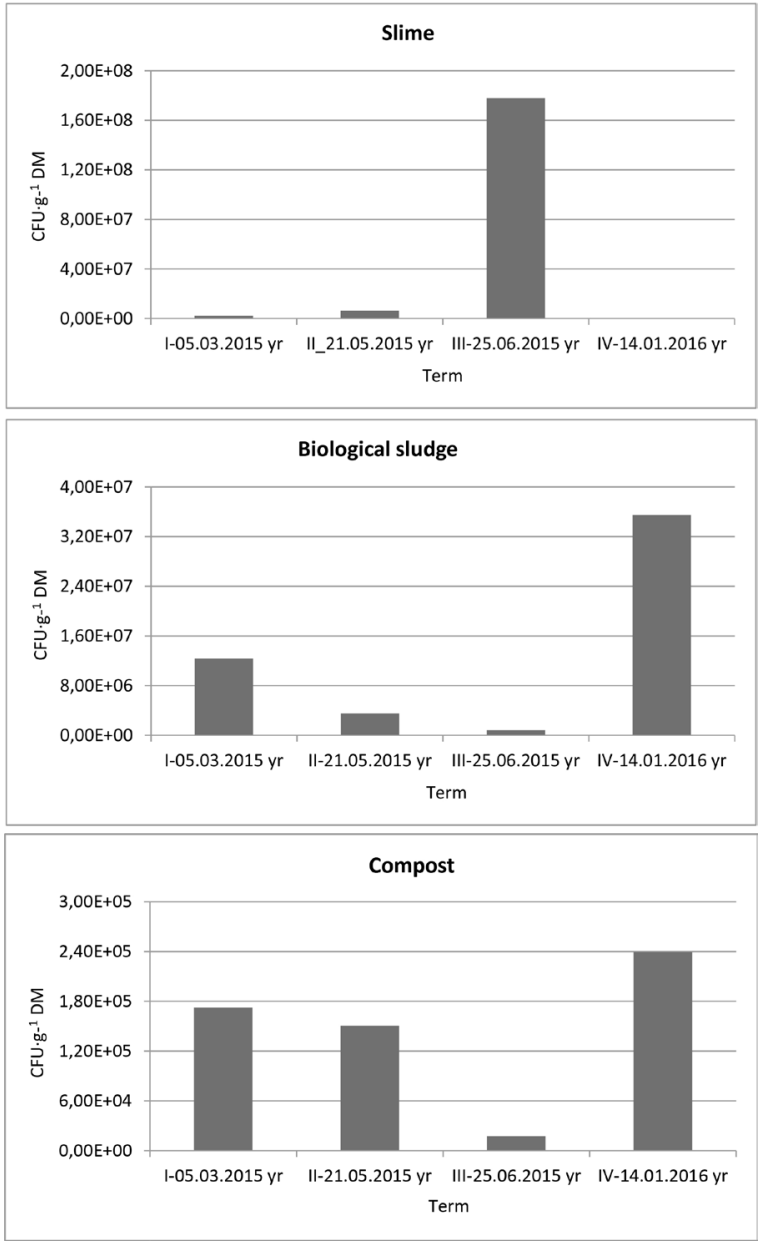

Figure 5-7. The number of keratinolytic microorganisms $\left(\mathrm{CFU} \cdot \mathrm{g}^{-1} \mathrm{DM}\right)$ on Mandela medium at various stages of poultry wastes management

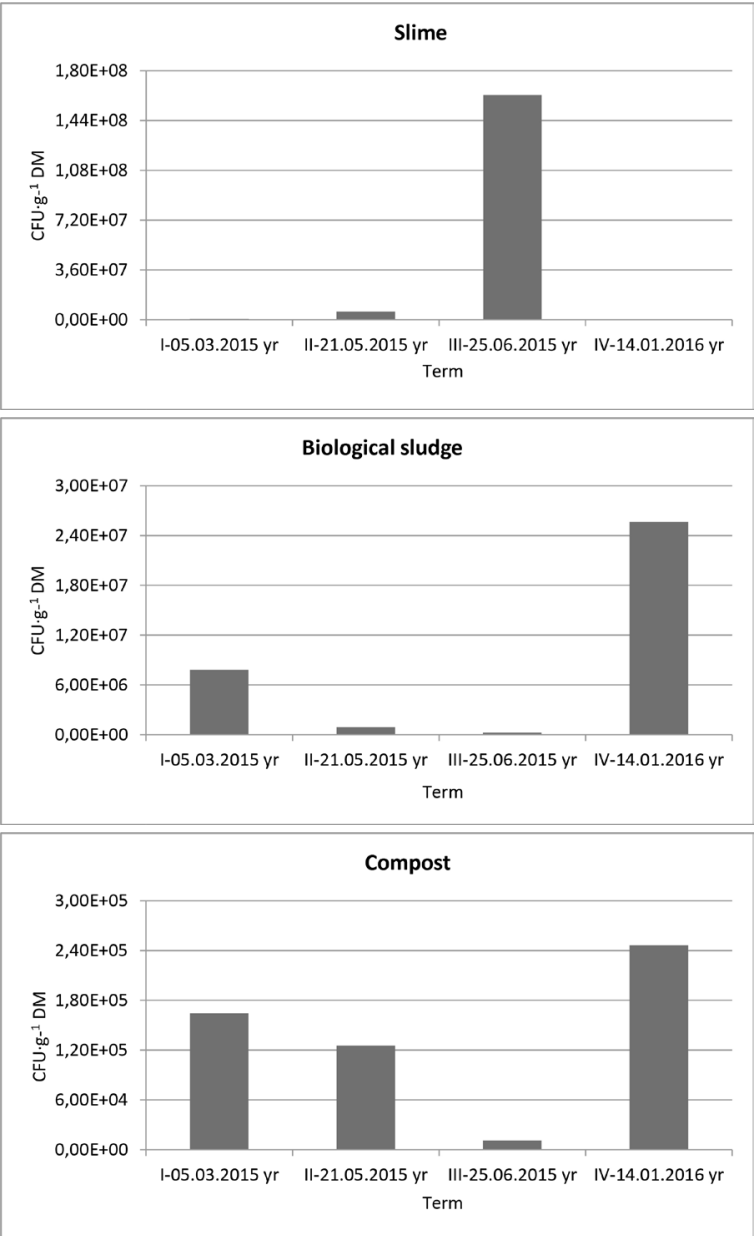

Figure 8-10. The number of keratinolytic microorganisms $\left(\mathrm{CFU} \cdot \mathrm{g}^{-1} \mathrm{DM}\right)$ on Omeliański medium at various stages of poultry wastes management 
at particular stages of management and variable ambient temperatures resulting from the sampling at different seasons of the year, were recorded (Figure 5-7, Figure 8-10).

Samples of slime from the liquid wastes reservoir proved to be the most populated by microorganisms for the growth and degradation of keratin (Figure 2). Larger numbers were shown by bacteria at the level of $4.7 \cdot 10^{7} \mathrm{CFU} \cdot \mathrm{g}^{-1} \mathrm{DM}$. Number of fungi in the slime was by $10 \%$ lower than that of bacteria; however this difference was not statistically confirmed (Figure 11-13).

Microorganisms, regardless of taxonomic group, inhabiting the slime from the liquid wasted after poultry processing, occurred most frequently during the summer months, i.e. the third measurement date. Environments, where keratin is present, are colonized by microorganisms having the ability to secrete enzymes necessary for its decomposition [Vasileva-Tonkova et al., 2009, Pillai and Archana, 2008]. Such abilities were found at bacteria [Ichida et al., 2001, ElRefai et al., 2005; Cai et al., 2008], actinomycetes [Gousterova et al., 2005] and fungi [Rodrigues Marcondes et al., 2008; Godheja and
Shekhar, 2014]. According to Ulfig et al. [1996], keratin-degrading microorganisms are numerous also in sewage sludge and soils [Brandelli et al., 2010].

Smaller numbers of keratinolytic microorganisms (24\%) were found in the tested biological sludge. Mean bacteria count ranged at the level of $1.3 \cdot 10^{7} \mathrm{CFU} \cdot \mathrm{g}^{-1} \mathrm{DM}$, while that of fungi in that material was significantly lower and the difference amounted to 30\% (Figure 11-13).

Muhsin and Hadi [2011] in their research found that there were various keratin-containing substrates in the sludge. Relatively large number of microorganisms in this type of waste, according to the authors, may indicate that the material is abundant in nutrients and much more readily available keratin protein necessary for their development.

The lowest numbers of microorganism able to decompose keratin were recorded in the compost. The average number amounted to $1.4 \cdot 10^{5} \mathrm{CFU} \cdot \mathrm{g}^{-1} \mathrm{DM}$. Number of microorganisms found in this material, regardless of the substrate for propagation, was at similar levels (Figure 11-13).
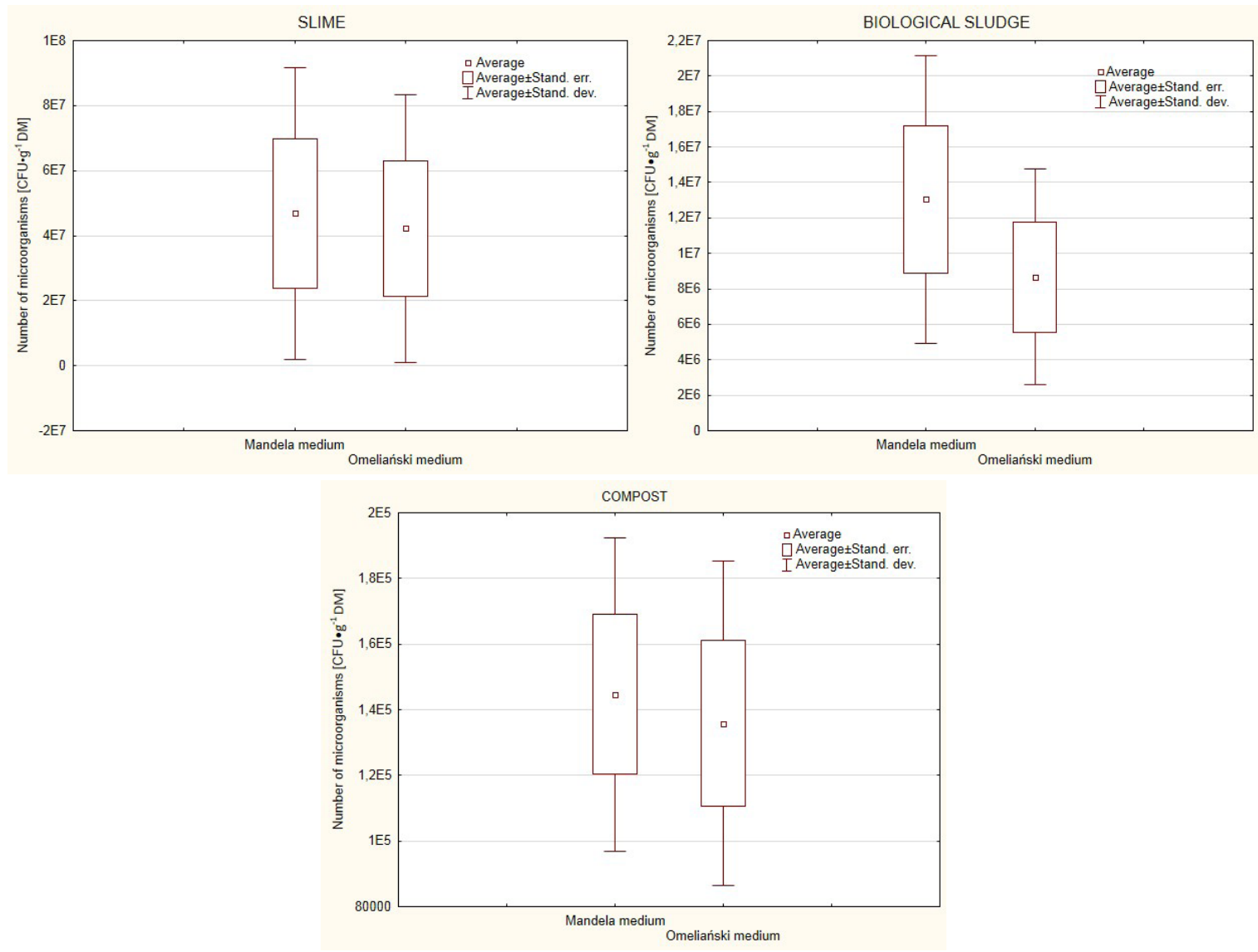

Figure 11-13. Characteristics of keratinolytic microorganisms number distribution in tested materials 
Both in the case of biological sludge and compost, higher numbers were observed in winter - IV test date (January 14, 2016). These materials were colonized by less keratin-degrading microorganism number in other dates, and when the temperature were higher, they were relatively minimal. Studies carried out by Shih [1993] revealed that compost produced from postslaughter wastes management was colonized by bacteria. In opinion of Marcinkowski [2010], process of poultry wastes composting do not affect the number of inhabiting bacteria, whereas significantly lowers the fungi number.

There were significant differences in the average number of bacteria and fungi between particular test materials (slime, biological sludge, proper compost) collected on various dates (Figure 3-4).

\section{CONCLUSIONS}

1. Poultry wastes at various stages of their management, up to the proper compost, were colonized by keratinolytic microorganisms - both bacteria and fungi. Their numbers depended on the phase of waste processing and sampling date.

2. Slime originating from the liquid wastes was material most often inhabited by microorganisms $\left(4 \cdot 10^{7} \mathrm{j} . t . \mathrm{k} \cdot \mathrm{g}^{-1} \mathrm{DM}\right)$ capable of degrading keratin, then biological sludge $\left(1 \cdot 10^{7} \mathrm{j} . \mathrm{t} . \mathrm{k} \cdot \mathrm{g}^{-1}\right.$ $\mathrm{DM})$ and to the lowest degree - proper compost $\left(1 \cdot 10^{5}\right.$ j.t.k.g $\left.{ }^{-1} \mathrm{DM}\right)$.

3. Biological sludge contained greater difference $(30 \%)$ in the number of fungi as compared to keratinolytic bacteria. In the compost and slime, studied taxonomic groups were at similar levels.

\section{REFERENCES}

1. Barone J.R., Schmidt W.F. 2006. Effect of formic acid exposure on keratin fiber derived from poultry feather biomass. Bioresource Technol. 97, 233242. DOI:10.1016/j.biortech.2005.02.039.

2. Bo X., Qiaofang Z., Xianghua T., Yunjuan Y., Zunxi H. 2009. Isolation and characterization of a new keratinolytic bacterium that exhibits significant feather-degrading capability. Afr. J. Biotechnol. 8 (18), 4590-4596.
3. Brandelli A., Daroit D.J., Riffel A. Biochemical features of microbial keratinases and their production and applications. 2010. Appl Microbiol Biotechnol. 85, 1735-1750. DOI 10.1007/s00253009-2398-5.

4. Cai C., Lou B., Zheng X. 2008. Keratinase production and keratin degradation by a mutant strain of Bacillus subtilis*. J Zhejiang Univ Sci B. 9(1), 6067. DOI:10.1631/jzus.B061620.

5. Cybulska K., Suchecka N., Wrońska I., MahdiOraibi S. 2015. The number of E. coli and C. perfringens bacteria in poultry waste and subsequent phases of composting. Proc. of ECOpole. 9(1), 1924. DOI: 10.2429/proc.2015.9(1)002.

6. El-Refai H.A., AbdelNaby M.A., Gaballa A., ElAraby M.H., Abdel Fattah A.F. 2005. Improvement of the newly isolated Bacillus pumilus FH9 keratinolytic activity. Process Biochem. 40, 2325-2332. DOI:10.1016/j.procbio.2004.09.006

7. Godheja J., Shekhar S.K. 2014. Biodegradation of Keratin from Chicken Feathers by Fungal Species as a Means of Sustainable Development. J Bioremed Biodeg. 5, 232. DOI:10.4172/21556199.1000232

8. Gousterova A., Braikova D., Goshev I., Christov P., Tishinov K., Vasileva-Tonkova E., Haertle T., Nedkov P. 2005. Degradation of keratin and collagen containing wastes by newly isolated thermoactinomycetes or by alkaline hydrolysis. Lett. Appl. Microbiol. 40(5), 335-340. DOI:10.1111/ j.1472-765X.2005.01692.x.

9. Grazziotin A., Pimentel F.A., de Jong E.V., Brandelli A. 2006. Nutritional improvement of feather protein by treatment with microbial keratinase. Anim Feed Sci Tech. 126, 135-144. DOI:10.1016/j. anifeedsci.2005.06.002.

10. Ichida J.M., Krizova L., LeFevre C.A., Keener H.M., Elwell D.L., Burtt Jr E.H. 2001. Bacterial inoculum enhances keratin degradation and biofilm formation in poultry compost. J Microbiol Methods. 47, 199-208.

11. Korniłłowicz-Kowalska T., Bohacz J. 2011. Biodegradation of keratin waste: Theory and practical aspects. Waste Management. 31(8), 1689-1701. DOI:10.1016/j.wasman.2011.03.024.

12. Mandels M., Weber J. 1969. Production of cellulases. Adv. Chem. Ser. 95, 391-414.

13. Marcinkowski T.A. 2010. Composting of Waste from Poultry Breeding - Biological Analysis. Chem. Biochem. Eng. 24 (3), 377-382.

14. Mazotto A.M., Couri S., Damaso M. C.T., Vermelho A.B. 2013. Degradation of feather waste by Aspergillus niger keratinases: Comparison of submerged and solid-state fermentation. International Biodeterioration \& Biodegradation. 85, 189-195. DOI: 10.1016/j.ibiod.2013.07.003. 
15. Muhsin T.M., Hadi R.B. 2011. Incidence of keratinolytic and dermatophytic fungi in sewage sludge in Basrah, Iraq. JBR-S. 37 (3 A), 1-9.

16. Pillai P., Archana G. 2008. Hide depilation and feather disintegration studies with keratinolytic serine protease from a novel Bacillus subtilis isolate. Appl Microbiol Biotechnol. 78, 643-650. DOI 10.1007/s00253-008-1355-z.

17. Rodrigues Marcondes N., Ledesma Taira C., Cirena Vandresen D., Estivalet Svidzinski T.I., Kadowaki M.K., Peralta R.M. 2008. New Feather-Degrading Filamentous Fungi. Microb Ecol. 56, 13-17. DOI 10.1007/s00248-007-9319-x.

18. Rozporządzenie Ministra Środowiska z dnia 9 grudnia 2014 r. W sprawie katalogu odpadów. Dz.U. poz. 1923.
19. Shih J.C.H. 1993. Recent development in poultry waste digestion and feather utilization. A review of Poultry Sci. 72, 1617-1620.

20. Ulfig K., Terakowski M., Plaza G., Kosarewicz O. 1996. Keratinolytic fungi in sewage sludge. Mycopathologia. 136, 41-46.

21. Vasileva-Tonkova E., Gousterova A., Neshev G. Ecologically safe method for improved feather wastes biodegradation. 2009. Int Biodeter Biodegr. 63, 1008-1012. DOI:10.1016/j.ibiod.2009.07.003.

22. Xu S., Reuter T., Gilroyed B.H., Mitchell G.B., Price L.M., Dudas S., Braithwaite S.L., Graham C., Czub S., Leonard J.J., Balachandran A., Neumann N.F., Miodrag Belosevic M., McAllister T.A. 2014. Biodegradation of Prions in Compost. Environ. Sci. Technol. 48, 6909-6918.DOI:10.1021/es500916v. 